\title{
水深積分型乱流エネルギー輸送方程式を連結させた 砕波帯内波動場モデルの提案
}

\section{1.はじめに}

最近の水の波に関する非線形波動理論の発展はめざま しいものがあるが，工学上重要となる砕波や砕波後の波 動場の取扱いに関しては，まだ多くの課題が残されてお り，物理性・一般性を兼坟備えたモデルは未だ確立され ていない.

既存の砕波モデルとして，拡散型ないしは抵抗型の減 衰項を付加するモデルがある. 例えば, 渡辺・丸山(1984) は時間発展型の緩勾配方程式に抵抗型の隇衰項を加える ことによって波高減衰を表現している．また片山・佐藤 （1986）は同様の減衰項を拡散型で評価し，Boussinesq 方 程式に付加している．しかし，これらの減衰項中のパラ メータが経験的に決められているものであることから， 任意地形での計算は困難である．Karambas \& Koutitas （1992）は拡散型の減衰項を付加した Boussinesq 方程式 に対して，減衰係数の時間平均の空間分布を時間平均乱 れエネルギーの収支から決定するモデルを提案してい る.しかし，このモデルでは波動場の準定常性が仮定さ れており研波帯が時間とともに変動する不規則波への拡 張性に問題がある.

一方, Schäffer ら (1992) は surface roller に基づく運 動量補正を取り込んだモデルを提案している。このモデ ルでは，砕波による乱れの効果を surface roller に集約 させていることからその精度が roller の見積もりに過度 に依存する形になるうえ，浮遊砂の算定等に必要となる 乱れ強度の見積もりには波動計算と別途に乱れの計算を 行う必要が出てくる.

柴山・Nguyen（1994）は簡単な渦粘性乱流モデルを取 り込んだ形のモデルで砕波帯の計算を行っている。しか し乱流場を単純なゼロ方程式モデルで扱っているため, 非一様斜面上の波動場のように，乱れの発生・消滅過程 の非平衡性が重要となる対象には本質的に適用が難しく なる。

本研究では，このような従来の砕波モデルの様々な限

* 正 会 員 工 博 東京工業大学教授 大学院情報理工学研究科情報 環境学専攻

** 学生会員 修(工) 東京工業大学大学院情報理工学研究科情報環境学 専攻博士課程
灘 岡 和 夫* • 大 野 修 史 ${ }^{* *}$

界を克服し，かつ海浜流や漂砂計算への応用性・実用性 をも具備した形の，新たな砕波モデルの基本的枠組みを 構築することを目的とした。

\section{2. 砕波帯内波動モデル}

\section{（1）モデルの定式化の基本的考元方}

モデル構築にあたっては,以下のポイントを考慮した。

1）乱流モデルとしては,任意地形上の砕波計算を可 能とするうえで本質的に重要となる，乱れの生成と消散 の非平衡性を考慮できるモデルとするため, 乱れの生成 と消散を含んだエネルギー輸送方程式をべースとする。

2）その場合, 非碎波領域の非線形波動方程式が何ら かの水深積分型のモデルであることから，それらと整合 させる意味で，水深積分型の乱流モデルとする。

3 ） 漂砂,特に浮遊砂の算定への応用の際に重要とな る，位相分布も含めた乱れ強度情報を与えることができ るモデルとする。

4）砕波による乱れの生成過程がその場の波形情報 等に強く依存していることから，乱流計算と波動計算を 連動した形のモデルとする。

\section{（2）波動方程式}

対象とする波動方程式としては，浅水方程式，Boussinesq 方程式など，非線形波動場の時間発展を記述する 水深積分型の方程式であればすべて対象となり，以後の 議論を同じように適用できるが，ここではこれらの方程 式を特別な場合として含む一般的な波動方程式である， 灘岡ら（1994）による多成分連成型の非線形分散性波動 方程式を対象とした（ただし，以下では簡単のため，一 次元（ $x$ 方向）波動場を前提として議論をすすめる).

この方程式は, 非回転の Euler の水平方向運動方程式 をべースとしているため, 回転成分が加わる砕波帯内に その形のままで適用することには問題があるが，ここで は議論を簡単にするために, 流速場の回転性を無視して, この方程式に以下のように Reynolds 応力項を加えた形 で定式化を行った（回転性を考慮したより本格的な取り 扱いについては別に報告する予定)。

$$
\frac{\partial u}{\partial t}+\frac{\partial}{\partial x}\left[g \eta+\int_{z}^{\eta} \frac{\partial w}{\partial x} d z+\frac{1}{2}\left(u_{s}^{2}+w_{s}^{2}\right)\right]
$$




$$
=\nu_{t}\left(\frac{\partial^{2} u}{\partial x^{2}}+\frac{\partial^{2} u}{\partial z^{2}}\right)
$$

ここに, 水平方向座標 $x$, 鉛直方向座標を $z$ とし, 各方 向の流速を $u, w$ としている.また $g$ は重力加速度で, $\nu_{t}$ は渦動粘性係数である. 式 (1) の右辺については, 鉛直積分によって第 2 項の寄与が小さくなることを考え て,第 1 項のみを以下の定式化では考慮している.流速 $u$ を変数 $U_{m}$ および波数成分 $k_{m}$ ，水深 $h$ により

$$
u=\sum_{m=1}^{M} \frac{\cosh k_{m}(h+z)}{\cosh k_{m} h} U_{m}
$$

と表現し,さらに, 簡単のため $\nu_{t}$ の分布を鉛直方向に一 様として，これらを連続式および水平方向運動方程式に 代入し, 灘岡らと同様の積分操作をすると, 以下の波動 方程式が得られる。

$$
\begin{aligned}
& \frac{\partial \eta}{\partial t}=\frac{\partial}{\partial x} \sum_{m=1}^{M}\left[\left(\frac{C_{m}}{g}+\eta\right) U_{m}\right] \\
& \sum_{m=1}^{M} A_{n m} \frac{\partial U_{m}}{\partial t}-\sum_{m=1}^{M} A_{n m} \nu_{t} \frac{\partial^{2} U_{m}}{\partial x^{2}} \\
& +g B_{n} \frac{\partial}{\partial x}\left[\left(\sum_{m=1}^{N} U_{m}\right)^{2}+w_{0}^{2}+2 \eta \frac{\partial w_{0}}{\partial t}\right] \\
& =\sum_{m=1}^{M} C_{n m} \frac{\partial^{3} U_{m}}{\partial x^{2} \partial t}+\sum_{m=1}^{N} D_{n m} \frac{\partial^{2} U_{m}}{\partial x \partial t}
\end{aligned}
$$

ここで $\eta$ は自由表面である。なお, 上式では底面せん断 力と水面せん断力をゼロとしている. 上式中の $A_{n m}, B_{n}$, $C_{m}, C_{n m}, D_{n m}$ は $\omega_{m}$ と水深 $h$ によって決定される係数 で，以下のように表せる。

$$
\begin{aligned}
A_{n m}= & \frac{\omega_{n}^{2}-\omega_{m}^{2}}{k_{n}^{2}-k_{m}^{2}}, \quad A_{n n}=\frac{g \omega_{n}^{2}+h\left(g^{2} k_{n}^{2}-\omega_{n}^{4}\right)}{2 g k_{n}^{2}} \\
B_{n}= & \frac{\omega_{n}^{2}}{k_{n}^{2}}, \quad C_{m}=\frac{\omega_{m}}{k_{m}} \\
C_{n m}= & \frac{B_{n}-A_{n m}}{k_{m}^{2}}, \quad D_{n n}=\frac{\partial}{\partial x} C_{n n} \\
D_{n n}= & \frac{2}{k_{m}^{2}-k_{n}^{2}}\left[\frac{2}{k_{m}} \frac{\partial k_{m}}{\partial x}\left\{A_{n m}-\left(k_{m}^{2}-k_{n}^{2}\right) C_{n m}\right\}\right] \\
& +\frac{\cosh k_{n} h \cdot \cosh k_{m} h}{\frac{\partial h}{\partial x}} \\
\omega_{m}^{2}= & g k_{m} \tanh k_{m} h
\end{aligned}
$$

式 (4) で減衰項として新しく加えられた項は式 (4) 左辺第 2 項である. 項中の動粘性係数 $\nu_{t}$ は次に述べる乱 流エネルギー $E$ と長さスケール $l$ により, $\nu_{t}=E^{1 / 2} l$ で表 される.

\section{（3） 水深積分型乱流モデル}

乱流モデルとしては,ここでは最も簡単なケースとし て乱れエネルギーのみの発生・消散・移流・拡散過程を 解く 1 方程式モデルを採用した（もちろん $l$ もしくは $\varepsilon$ を unknownとして扱う 2 方程式モデルによる定式化も 可能である). 2.（1）の 2) で述べたように，ここでは
波動方程式が水深積分型のモデルであることに対応し て, 乱れエネルギー方程式の水深積分操作を行うが, 簡 単のために乱れエネルギーの鉛直分布を一様とすると, 次式が得られる。

$$
\frac{\partial E}{\partial t}+\bar{u} \frac{\partial E}{\partial x}=P_{k}-\varepsilon+D_{k}
$$

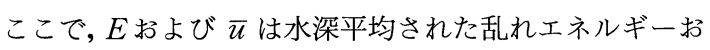
よび水平方向流速で, 右辺の $P_{k}$ および $\varepsilon, D_{k}$ はそれぞれ 乱れの生成項および消散率, 拡散項であり, $\varepsilon, D_{k}$ は次式 で与えられる。

$$
\begin{aligned}
& \varepsilon=c^{*} \frac{E^{3 / 2}}{l} \cdots \ldots \ldots . . . \\
& D_{k}=\frac{\partial}{\partial x}\left(\frac{\nu_{t}}{\sigma_{k}} \frac{\partial E}{\partial x}\right)
\end{aligned}
$$

上式中の $c^{*}, \sigma_{k}$ はモデル定数であるが, ここでは, これ らの值として, 標準的な值である $0.18,1.0$ を用いてい る、渦動粘性係数や乱れの消散率の算定に必要となる乱 れの長さスケール $l$ としては, ここでは, Svendsen (1987) を参考に, $l=0.2 h$ ( $h$ : 水深) として与えた.

\section{（4）乱れの生成項のモデル化}

砕波帯内の非平衡乱流計算のためのモデル構築に際し てキーポイントとなるのは, 砕波による乱れの生成項の 見積もりである，既存の砕波帯内波動モデルで，乱れの 取り扱いを, 物理性を持ったクローズした形で行うこと ができていない最大の原因が，この乱れ生成項のモデル の不在にあるといっても過言ではない.

壁面乱流の場合と違って, 砕波の乱れの主要な生成原 因が, bore 前面での大規模渦の生成にあることは疑う余 地がない.この大規模渦に関する従来の取り扱いは，定 常的な取り扱いがほとんどで, いわゆる surface roller モデルはその典型である. 砕波エネルギー減衰の評価に 関してよく用いられる hydraulic jump モデルも定常渦 的なイメージが前提にある. しかし, 実際の bore 前面で の大規模渦生成過程は決して定常的ではなく, ある程度 の周期性をもった生成プロセスであり, ある大きさの循 環とエネルギーを持って生成された大規模渦は, それぞ れ bore 後方に移流拡散されていく（図一1, 灘岡ら, 1985). そこでここでは, このような bore 前面での大規 模渦の準周期的な生成過程に着目し, 砕波による渦度の 供給過程をモデル化した, 灘岡・広瀬（1986）のモデル をベースとして, 乱れの生成項のモデル化を行った。

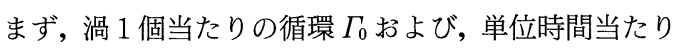
の大規模渦の発生個数 $n$ を用いれば, 一波内の単位時間 当たりの渦度供給量 $\Omega$ は

$$
\Omega=n \Gamma_{0}
$$

となる.ここで $n$ は $n=\Gamma_{0} / 2\left(\pi r_{0}\right)^{2}\left(r_{0}\right.$ : 渦の半径 $)$ で見 


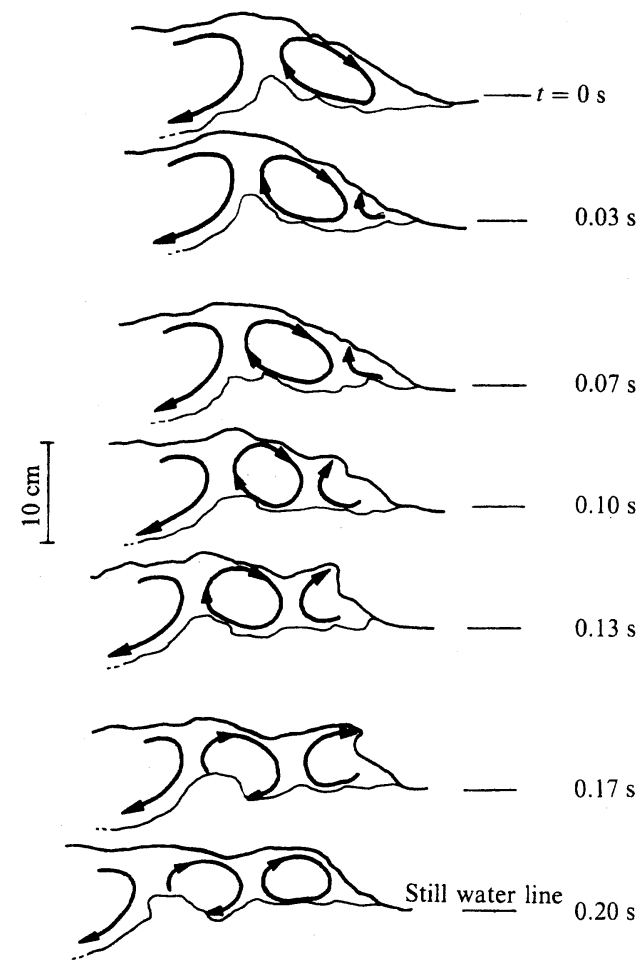

図一1 bore 前面での大規模渦の準周期的生成過程（灘岡ら， 1985)

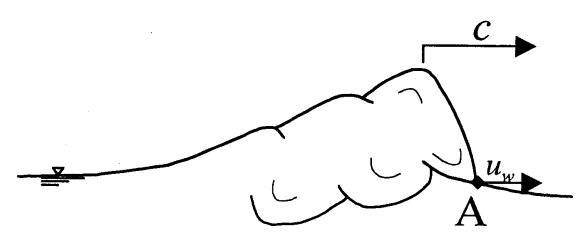

図一2 乱れの供給過程の概念図

積もられる. 運動エネルギーを Rankine 渦でモデル化す ると，大規模渦として生成される単位時間当たりのエネ ルギー $E_{L}$ は次式で表される。

$$
E_{L}=\frac{\rho \Gamma_{0}^{3}}{16\left(\pi r_{0}\right)^{2}}
$$

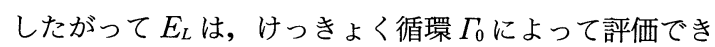
ることがわかる。

循環 $\Gamma_{0}$ の見積もり方として，ここでは図一2 の bore 前面での A 点 (この点は数学的には特異点) での平均的 な渦度供給量が, 式 (8) で示した大規模渦による渦度 供給量と等しいとおくことによって $\Gamma_{0}$ を算定した。A点 での平均的な渦度供給量 $\Omega$ は, bore の波速を $c, \mathrm{~A}$ 点で の波動流速を $u_{w}$ として

$$
\Omega=\frac{\left(u_{w}-c\right)^{2}}{2} .
$$

と表すことができる(灘岡ら, 1992).したがって, 式( 8 ), 式（10）を等置することにより,

$$
\Gamma_{0}=\pi r_{0}\left(u_{w}-c\right)
$$

が得られる.

乱れの供給される区間の長さを $L_{1}$ とすると，乱れの 生成項は $P_{k}$, 最終的に次式で評価されることになる.

$$
P_{k}=\frac{\pi r_{0}\left(u_{w}-c\right)^{3}}{16(h+\eta) L_{1}} \text {. }
$$

ここで, $u_{w}$ については, A 点が zero-cross 点近傍にある と仮定すれば， $u_{w}=0$ と見積られる。 また同様の仮定か ら，ここでは $L_{1}$ として波頂部から zero-cross 点までの 距離を,さらに渦のスケール $r_{0}$ として波峰高 $a_{1}$ の $1 / 2$ を与えた。

砕波の判定および波の再生の判定には, 灘岡ら (1996) によって最近提案された波頂部付近の圧力勾配に基づく 砕波判定基準を用いた。 そして, 各時刻において, 自由 表面上の圧力勾配が負である波は砕波しているものとし て, 区間 $L_{1}$ にわたって式（12）で表される乱れエネル ギーを供給し, 自由表面上の圧力勾配が再び正になれば 乱れの供給を 0 とした。

\section{4. 計 算 例}

上記のモデルを用いて，いくつかの波動場について数 値計算を行った結果について示す．数值計算に用いた時 間解像度 $\Delta t$ は $\Delta t=T / 70$ （ $T$ : 波の代表周期）とした。 また空間解像度 $\Delta x$ は水深に応じて変化させており, 各 水深における線形理論の波速より得られる Courant 数 が $1 / 3$ となるように選んでいる.岸側の境界は, 有限の水 深での透過条件とし, 波の這い上がりなどは考慮してい ない.

\section{（1）一様斜面上の規則波の砕波}

最も基本的なケースの計算例として, 図一 2 に示すよ うな $1 / 50$ 斜面に, 周期 $8 \mathrm{~s}$, 沖波波形勾配 0.02 の正弦波 を入射した場合の計算結果を図一4に示す. 図の上段が 自由表面波形 $\eta$, 下段が乱れエネルギー $E$ の時空間分布 を示しており, 図の横軸が空間座標 $x$, 縦軸が経過時間 を示している．図より，波の前部で大きな乱れが生じ波 高が減衰していく様子が良好に表現されていることがわ

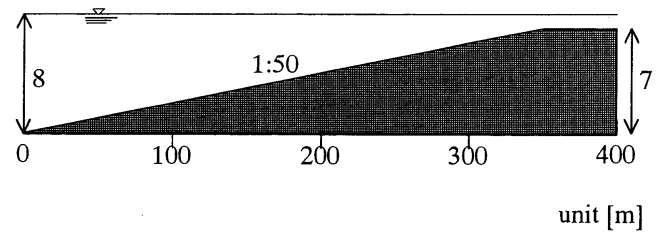

図-3 数值実験斜面 $\mathrm{A}$ 

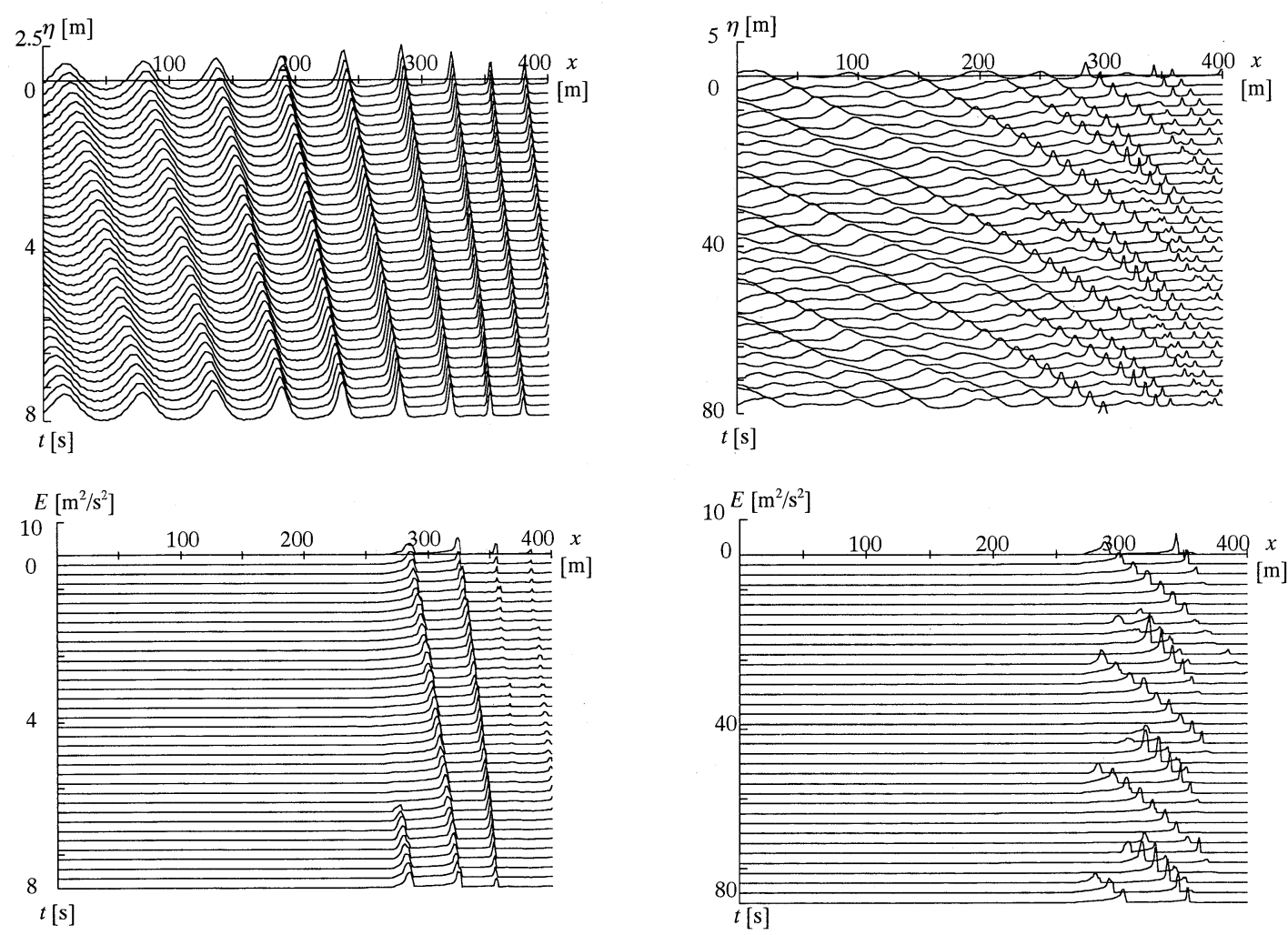

図-4 一様斜面上で砕波する規則波の自由表面および乱れ エネルギーの時空間変動

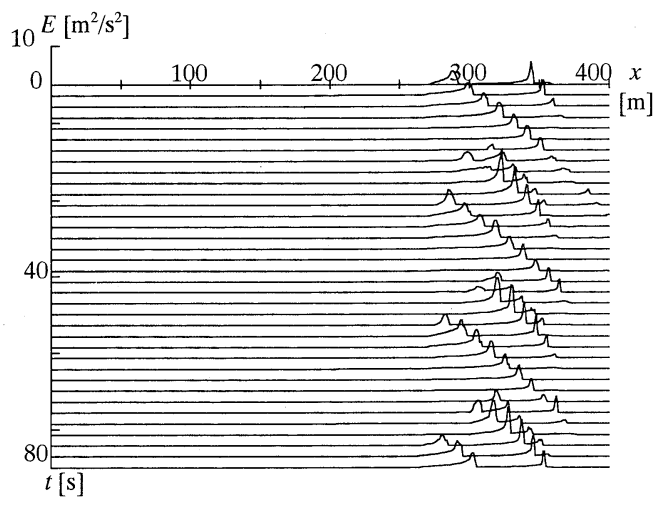

図一5一様斜面上で砕波する不規則波の自由表面および乱 れエネルギーの時空間変動

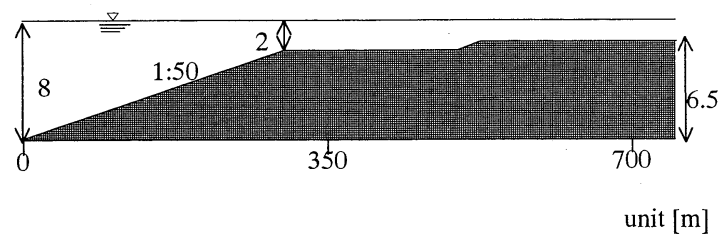

図一6 数値実験斜面 B

(1) と同様の斜面に,有義周期 $8 \mathrm{~s}$ の Bretschneider 型入 ペクトルをもつ不規則波を入射した場合の計算結果を 図一5に示す。これから砕波発生位置が不規則に変動し ている様子が再現されていることがわかる.

\section{（3） 2 段ステップ上の規則波の砕波}

ステップ地形上の砕波しつつ進行する波は, 乱れの生 成と消散の非平衡性が影著となる典型例である.ここで は，図一6に示すような 2 段ステップ斜面に周期 $8 \mathrm{~s}$, 沖 波波形勾配 0.02 の正弦波を入射した。 その計算結果を 図一7 に示す.これから，一度砕波した波が，一様水深部 で乱れエネルギーがゼロとなり波が再生し，2段目のス テップで再び砕波が発生して, 再度, 乱れエネルギーが 生じ波高が減衰する様子が表現されていることがわか る.

\section{6. おわりに}

水深積分型の乱れエネルギー輸送方程式を波動方程式 と連結させた形の新たな砕波帯内波動モデルの基本形を 示した. その際, 特に重要となる乱れの生成項をここで は bore 前面での準周期的な大規模渦に着目し, 大規模渦 によるエネルギー生成を渦度供給モデルをベースとして 具体的に算定する方法を提案した。そして，いくつかの 計算例を通じて, 本モデルにより, 砕波変形過程ととも に乱れエネルギーの生成・輸送過程を比較的良好に表現 することができることを示した.

ただし，本論文の段階では，冒頭の 2.（1）で述べた, 基本スタンスに立ったモデル化について，その基本的な 

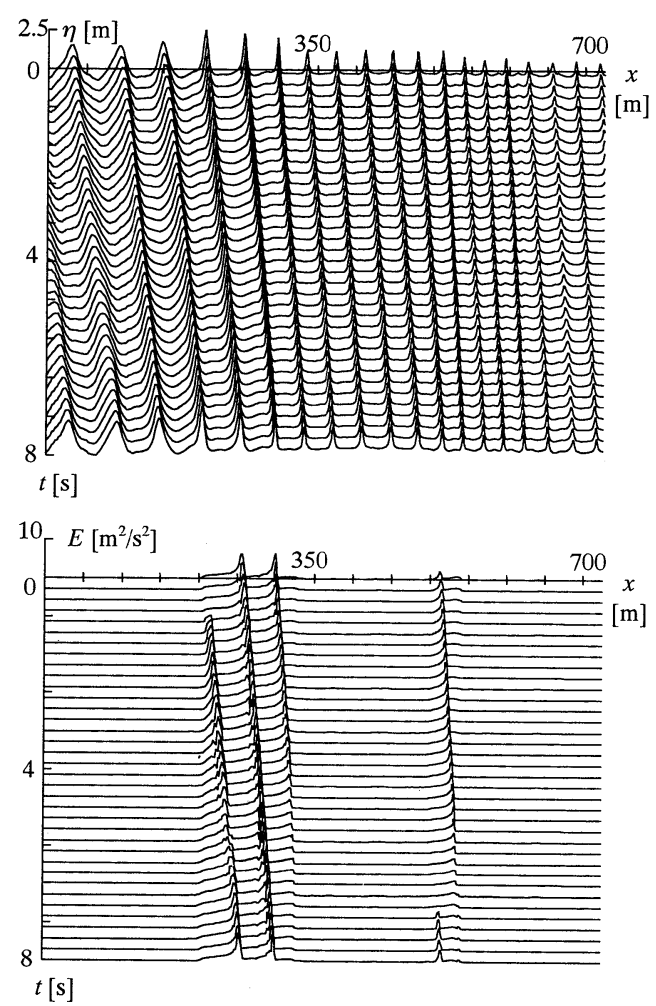

図一7 2 段ステップ上での規則波の自由表面および乱れエ ネルギーの時空間変動

枠組みを具体化したに過ぎない，現段階では，本文中に 記しているょうに，モデル定式化上のいくつかの簡略化 や仮定を持ち込んでいる。これらのうち，例えば流速の 非回転性の仮定や，乱れエネルギーの鉛直方向一様性の 仮定などは, 定式化が多少複雑になることを厭わなけれ ば,はずせる仮定である。しかし今回のモデルの重要な ポイントとなっている, bore 前面での大規模渦の評価に ついては，今後任意の地形・波浪条件に対応できるよう にするために，より一般的なモデル化を行っていくこと
が不可欠である。これについては今後の課題としたい.

謝辞：本研究は, 文部省科学研究費補助金基盤研究 （B）（2）「新たな一般波動理論体系の確立に基づく沿岸 水理解析の新展開」(代表者：灘岡, 課題番号：08455228) の補助を受けて行われたものである.ここに記して謝意 を表します。

\section{参考文 献}

片山祐之・佐藤槙司（1986)：Boussinesq 方程式を用いた不規則 波の浅水 ・砕波変形の計算法, 第 33 回海岸工学講演会論文 集, pp. 26-30.

柴山知也・Nguyen. T. D (1994)：乱流方程式を用いた砕波帯内 波浪場の数值モデル, 海岸工学論文集, 第 41 巻, pp. 151-155

灘岡和夫・小谷野喜二・日野幹雄 (1985): 二成分光ファイバー 流速計を用いた砕波帯内流速場の特性の解明, 第 32 回海岸 工学講演会論文集, pp. $50-54$.

灘岡和夫・広瀬文人（1986）：砕波の物理過程に基づいた砕波帯 内の拡散係数のモデル化, 第 33 回海岸工学講演会論文集, pp. $26-30$.

灘岡和夫・八木 宏・悦道博之 (1992)：鉛直分布構造を考慮し た海浜流のモデル化に関する研究, 海岸工学論文集, 第 39 巻, pp. 151-155.

灘岡和夫・Serdar Beji・大野修史（1994）：新たな波動モデルに よる強分散性非線形場の解析法の確立と室内実験による検 証, 海岸工学論文集, 第 41 巻, pp. 11-15.

灘岡和夫 - 大野修史・栗原 礼 (1996)：波動場の力学状態に基 づく砕波過程の解析と砕波条件, 海岸工学論文集, 第 43 巻, pp. $81-85$.

渡辺 晃 - 丸山康樹 (1984)：屈折 - 回折 - 砕波減衰を含む波浪 場の数值解析法, 第 31 回海岸工学講演会論文集, pp. 26-30.

Karambas, T. V. and C. Koutitas (1992): A breaking wave propagation model based on the Boussinesq equations, Coastal Eng., Vol. 18, pp. 1-19.

Svendsen, I. A. (1987): Analysis of surf zone turbulence, J. Geophys. Res, 92, pp. 5115-5124.

Schäffer. H. A, Deigaard. R and Madsen. P (1992): A twodimensional surf zone model based on Boussinesq equations, Proc. 24 th Int. Conf. Coastal Eng., ASCE, pp. 576-589. 